\title{
Prospective Plants with Corroborated Antimalarial Actions: A Review
}

\author{
Anika Tabassum Obonti, Safaet Alam, Taslima Binte Kamal, Anika Zaman, Hasin \\ Hasnat, Tanoy Saha and Md. Ashraful Islam
}

\author{
Department of Pharmacy, State University of Bangladesh, 77 Satmasjid Road, Dhanmondi, \\ Dhaka-1207, Bangladesh.
}

(Received: May 15, 2021; Accepted: July 6, 2021; Published (Web): July 15, 2021)

\begin{abstract}
Malaria is a serious illness resulted from parasites that are communicated to people through the bites of infected female Anopheles mosquitoes. Malaria is still in a worrying trend, particularly in tropical and subtropical climates although it is curable and preventable. In spite of a noteworthy abetment in incidence and death rates caused by malaria, even in 2017, a big number of people (219 million) have been affected by it along with 435 thousand confirmed death cases. Though a lot of synthetic drugs have been commercialized to treat malaria, those are compromised with some serious side effects. On the contrary, plant sources are always getting a big focus to develop novel and effective therapeutics in the treatment of different ailments i.e. quinine and artemisinin to treat malarial complications. The usage of herbal plants against malaria has also a very ancient root. Several families of plant species have showed potential antimalarial activities in previous research works. In this review work, families of these plants have been compiled so that prospective researchers can find a hint to discover more effective and safer plant-derived therapeutic options against malaria.
\end{abstract}

Keywords: Malaria, Plants, Antiplasmodial, Ethnobotany, Plasmodium falciparum.

\section{Introduction}

Malaria is a generic word for protozoa of the Plasmodium genus that is frequently used in conjunction with the term "Malaria parasites". It is defined as an ailment or disease state resulted from parasites of this genus in the blood or tissues of a person. Presence of the parasites at any stage in the human body suggests the existence of malarial infection (Hempelmann et al., 2013). Mosquitoes preserved in amber dating back 30 million years ago provided the first proof of the presence of malaria (Poinar, 2005). During the Middle Ages, the disease continued to be a problem, when malaria epidemics caused the coastal plains of Italy and England to lose their global dominance (Dobson, 1994). Though, between 2000 and 2015, the incidence and death rates declined by $37 \%$ and $60 \%$, respectively worldwide (WHO, 2016). It causes deaths of around one million people per year in the tropical and subtropical zones (Mojarrab et al., 2014). Eventually, around $90 \%$ of cases of malaria have been ascertained in SubSaharan Africa, (Nguta et al., 2010). Even in 2017, Africa still has the highest burden of malaria calamity, with 200 million cases which attribute to $92 \%$ of total cases (WHO, 2018). Research showed that, the disease affects 4 to 5 million Ethiopians each year (Ayele et al., 2012) with 70,000 mortalities (PMI, 2008). 219 million cases of malaria recorded globally in 2017 with an increment of almost 2 million cases than the previous year, resulting in 435 thousand deaths, which attributes to 1190 death per day (WHO, 2018). WHO stated that malaria caused

Corresponding author: Safaet Alam; Email: safaet.du@gmail.com

DOI: https://doi.org/10.3329/bpj.v24i2.54716 
by $P$. falciparum was responsible for $99 \%$ case of all malaria associated deaths (WHO, 2015; Alebie et al., 2017). Even in Bangladesh, malaria is endemic in 13 of 64 Bangladeshi districts and a total of 14 million individuals are in danger. But with a ray of hope like other countries, malaria incidences are in a declining phase in Bangladesh too (6.2 per 1000 people in 2008 to 2.1 per 1000 people in 2012) (Haque et al., 2014).

Many synthetic drugs like chloroquine, mefloquine, atovaquone-proguanil, doxycycline, and artemisinin derivatives are used for malaria treatment (Grabias and Kumar, 2016). However, several neuropsychiatric adverse effects including nausea, headache, vertigo, loss of balance, depression, sleep disturbances, psychoses have been recorded for these antimalarial drug options. Moreover, neurotoxic, gastrointestinal, and genitourinary adverse effects like vomiting, abdominal pain, and vaginitis along with teratogenic adverse effects were also observed from those drugs (Grabias and Kumar, 2016). These conventional antimalarial drugs are often expensive and/or unavailable in many malaria-affected populations. Besides, developing drug resistance by the malaria parasite $P$. falciparum is another major issue which becomes a major concern nowadays (Greenwood and Mutabingwa, 2002). For these reasons, the urge to discover novel and effective antimalarial drugs with unique modes of action has become more pronounced (Ogbuehi et al., 2013).

Plants are very good sources of therapies to treat different kinds of illness from the ancient age (Alam et al., 2020; Emon et al., 2020). Natural products derived from plants have recently become the focus of attention as a primary source of innovative, safer, and more effective secondary bioactive metabolites with therapeutic capabilities (Emon et al., 2021; Rudra et al., 2020; Ogbuehi et al., 2013). Almost $80 \%$ of all drug products are either directly derived from plants or their modified forms (Alam et al., 2021). The history of plant products against malaria has a very ancient root (Muthaura et al., 2007). Based on ethnobotanical leads, initially, antimalarial drugs like artemisinin and quinine were derived from the herbaceous plants Artemisia annua L. and Cinchona pubescens Vahl., respectively (Wongsrichanalai, 2002). Till 2004, almost 1277 plants from 160 families have been reported with promising antimalarial activities (Rasoanaivo et al., 2011; Uzor et al., 2020). In different studies, various phytochemicals including alkaloids, indole alkaloids, naphthoisoquinolines, furoquinolines, acridones, amides, cryptolepines, terpenoids, clerodane and labdane diterpenoids, bisnorterpenes, acyclic triterpenes, cassane furanoditerpenes, abietane diterpenes, coloratane sesquiterpenes, beilshmiedic acid derivatives, pentacyclic triterpenes were found active against the disease (Onguéné et al., 2013). In this review article, we have classified plants based on their family who have showed antimalarial properties in previous researches so that prospective researchers, drug developers and other related personnel can find a contemporary clue in order to facilitate the discovery of novel and effective antimalarial therapeutics.

\section{Materials and Methods}

Article search strategy: An extensive literature search was conducted using several online databases including Web of Science, Scopus, PubMed/Medline, ScienceDirect, Wiley Online Library, and Google Scholar during this review. We have used 'Antimalarial', 'Antiplasmodial', 'Malaria', 'Plasmodium', 'Plant products' and 'Herbal' as key words to gather the related information. Considering peer reviewed and published articles only, describing malaria and role of plants and plant products against malarial complications as inclusion criteria, 118 out of 253 distinct articles were included in this review.

\section{Notable plant families with antimalarial actions}

\section{Annonaceae}

Enantia chlorantha Oliv. is an ornamental tree with thick leaf and a spreading crown and grows to a height up to $30 \mathrm{~m}$. It is found in densely wooded forests in east and south part of Cameroon, as well as in the south section of Nigeria, Angola, Gabon and the Democratic Republic of the Congo (Tcheghebe et al., 2016). In Cameroon, the stem bark of $E$. 
chlorantha was commonly used to cure malaria, jaundice and various fevers (Adjanohoun et al., 1996). The aqueous extract of E. chlorantha was shown to be efficient to ameliorate $P$. yoelii infection in mice after administered orally in drinking fluid at $0.2-150 \mathrm{mg} / \mathrm{ml}$, but no effect was seen when administered via oral cannulation or subcutaneously. The ethanol extract of $E$. chlorantha also exhibited effective result in eliminating the parasites after being administered subcutaneously in doses of $0 \cdot 05-0 \cdot 5$ mg/g (Agbaje and Onabanjo, 1991).

Annona muricata $\mathrm{L}$., an evergreen tree which is typically $5-10 \mathrm{~m}$ tall, has low branches with a diameter of $15-83 \mathrm{~cm}$. It is seen in Central and South America's tropical areas, as well as Southeast Asia and Western Africa (Coria-Téllez Et al., 2018). A. muricata aqueous leaf extract demonstrated strong $\mathrm{LC}_{50}$ and $\mathrm{LC}_{90}$ values against third instar larvae of Aedes aegypti $\quad\left(\mathrm{LC}_{50} \quad 51.13 \mu \mathrm{g} / \mathrm{ml}\right.$ and $\mathrm{LC}_{90}$ $82.08 \mu \mathrm{g} / \mathrm{ml}) \quad$ Culex quinquefasciatus $\left(\mathrm{LC}_{50}\right.$ $88.72 \mu \mathrm{g} / \mathrm{ml}$ and $\mathrm{LC}_{90} 151.30 \mu \mathrm{g} / \mathrm{ml}$ ) and Anopheles stephensi $\left(\mathrm{LC}_{50} 61.38 \mu \mathrm{g} / \mathrm{ml}\right.$ and $\left.\mathrm{LC}_{90} 156.55 \mu \mathrm{g} / \mathrm{ml}\right)$ (Santhosh et al., 2015.)

Xylopia parviflora Spruce is a small tree with a height of up to $3 \mathrm{~m}$. It is native to East Africa (Woguem et al., 2014). The methanol extracts of leaves and stem from $X$. parviflora had a strong antiplasmodial activity with $\mathrm{IC}_{50}$ values ranging from 1.07 to $5.83 \mathrm{~g} / \mathrm{ml}$ (Boyom et al., 2011).

\section{Apocynaceae}

Rauvolfia vomitoria Afzel. is a small tree that grows to around $15 \mathrm{~m}$ in height and can be found widely all over the world, especially in Asia and West-African countries (Olatokunboh et al., 2009). Water, hexane, dichloromethane and methanol extracts from leaves of $R$. vomitoria demonstrated a very effective antimalarial activity against chloroquine-sensitive NF54 strains of $P$. falciparum with $\mathrm{IC}_{50}$ values ranging from 0.63 to $20.19 \mu \mathrm{g} / \mathrm{ml}$ ) (Cynthia, 2018).

Holarrhena floribunda (G.Don) T.Durand \& Schinz, called faux rubber tree, is a $4.5-15 \mathrm{~m}$ tall shrub to a medium-sized tree (Ahmed 2017). The leaf extract of $H$. floribunda decreased parasitaemia caused by $P$. berghei with $6.96 \%, 29.06 \%$, and $37.71 \%$, respectively at 100,250 , and $500 \mathrm{mg} / \mathrm{kg}$ body weight doses (Hoekou et al., 2017).

Tithonia diversifolia (Hemsl.) A.Gray, generally termed as Mexican sunflower, is a perennial or annual shrub which typically grows to a height of $1.2-3 \mathrm{~m}$. It is native to North and Central America, but has been naturalized in Africa, Australia, and Asia too (Ajao and Moteetee, 2017). The aqueous and methanol extracts of leaves of $T$. diversifolia were $50 \%$ and $74 \%$ effective against $P$. berghei and the $\mathrm{LC}_{50}$ of the aqueous extract was found to be $1.2 \mathrm{ml} / 100 \mathrm{~g}$ body weight in mice (Oyewole et al., 2008).

\section{Asteraceae}

Artemisia апnиa L., commonly known as sweet wormwood, sweet annie or sweet sagewort is an annual herb growing more than $2 \mathrm{~m}$. This herb is native to Asia mainly China, but has been naturalized all across the world including the United States (Das, 2012). Based on previous research work, $72 \mathrm{~g}$ of $A$. annua crude alcohol extract was $100 \%$ effective against $P$. vivax and $P$. falciparum, while $20 \mathrm{~g}$ and 35 $\mathrm{g}$ aqueous infusions of $А$. аппиа were $100 \%$ and $93 \%$ effective against $P$. falciparum, accordingly. $A$. аппиа aqueous decoction was also $92 \%$ effective at $20 \mathrm{~g}$ amount against P. falciparum (Willcox et al., 2004). Artemisinin, extracted from the leaves of this Chinese plant has a very pronounced antimalarial application (Tajuddeen and Heerden, 2019). Coadministration of artemisinin with other drugs or its derivative i.e. artesunate has been considered as effective combination therapy to treat multi-drug resistant malaria (Batista et al., 2009).

\section{Bignoniaceae}

Spathodea campanulata P.Beauv., popularly known as the African tulip tree, is broadly spread throughout Africa and found numerously in Cameroon also. (Ngouela et al., 1991). The hexane and chloroform extracts of $S$. campanulata exhibited inhibitory action against $P$. berghei and suppressed malaria in mice models (Amusan et al., 1996). 


\section{Capparidaceae}

The evergreen perennial shrub, Buchholzia coriacea Engl. commonly known as "Wonderful kola" is found in African nations such as Nigeria, Ghana, and Liberia. B. coriacea seeds were found to decrease parasitemia levels substantially. The seed extracts $(20,40$, and $600 \mathrm{mg} / \mathrm{kg}$ body weight dose) were administered for four days continuously to find the desired actions (Enechi et al., 2021).

Cleome rutidosperma DC. is a low-growing shrub with trifoliate foliage and tiny violet-blue blooms that become pinks with the age. It is found in waste grounds and grassy areas. The plant is native to West Africa, but it has been naturalized in many regions of tropical America and Southeast Asia including Malaysia and India (Ghosh et al., 2019). Ethanol extract of the plant had shown moderate effect against $P$. falciparum strain with $\mathrm{IC}_{50}$ value of $34.4 \mu \mathrm{g} / \mathrm{ml}$ whereas diethyl ether extract demonstrated a good antiplasmodial effect with $\mathrm{IC}_{50}$ value of $8.1 \mu \mathrm{g} / \mathrm{ml}$ (Bose et al., 2010).

\section{Clusiaceae}

Allanblackia monticola Mildbr. ex Engl. is a big forest tree that occurs in Cameroon's West and South regions. The methanol extract of A. monticola had $\mathrm{IC}_{50}$ ranging from 0.6 to $8.9 \mathrm{~g} / \mathrm{ml}$ on $P$. falciparum F32 and FcM29 strains (Azebaze et al., 2007).

\section{Combretaceae}

Terminalia superba Engl. \& Diels is a large deciduous tree with a stem diameter of $120 \mathrm{~cm}$ and a height of $30-50 \mathrm{~m}$. T. superba is native to West and Central Africa (Kuete et al., 2010). The aqueous extract from leaves of $T$. superba showed a very good antiplasmodial activity and selectivity with $\mathrm{IC}_{50}$ values ranging from $0.57 \mu \mathrm{g} / \mathrm{ml}$ and $1.26 \mu \mathrm{g} / \mathrm{ml}$ on PfINDO and Pf3D7 strains of $P$. falciparum, respectively (Mbouna et al., 2018).

\section{Euphorbiaceae}

Alchornea cordifolia (Schumach. \& Thonn.) Müll.Arg. often known as Schum-Thron, is a shrubbery plant that grows throughout coastal regions of West Africa (Osadebe and Okoye, 2003). Ethanol extract of A. cordifolia leaves had moderate in vitro activity over $P$. falciparum in the mice model though chloroform and ether extracts didn't show any promising action (Banzouzi et al., 2002).

Euphorbia hirta L. is a reddish or purplishcolored, slender-stemmed, annual plant with many branches from the ground to the top reaching a height of up to $40 \mathrm{~m}$. E. hirta is found in landfill areas along roadsides in the hotter areas of India and Australia (Kumar et al., 2010). The methanol extract of E. hirta aerial parts exhibited major active chromatographic fractions that inhibited $P$. falciparum growth by $90 \%$ at $5 \mathrm{~g} / \mathrm{ml}$ concentration (Liu et al., 2007).

\section{Fabaceae}

Cajanus cajan (L.) Millsp. is a perennial or annual leguminous plant which is broadly distributed in tropical and subtropical portions of the world including Asia, Africa and South America (Kong et al., 2010). C. cajan leaf extract inhibited the growth of $P$. falciparum at $\mathrm{IC}_{50}$ value of $2.0 \mu \mathrm{g} / \mathrm{ml}$ (Ajaiyeoba et al 2013).

\section{Leguminosae}

Guibourtia coleosperma (Benth.) Leonard or giant false mopanie, is a tree native to southern Africa which can be found in Namibia, Zambia, Zaire, Zimbabwe and Angola also (Bekker et al., 2006). G. coleosperma aqueous and organic extracts both had moderate antimalarial activity, with $\mathrm{IC}_{50}$ values of 31.61 and $28.17 \mathrm{~g} / \mathrm{ml}$, respectively (du Preez et al., 2020).

\section{Liliaceae}

Allium sativum L. is a fragrant herbaceous plant that grows up to 30 to $80 \mathrm{~cm}$ tall (Sendl., 1995). A. sativum is thought to have evolved in Central Asia 600 years ago and has subsequently expanded over Southwest Asia and the Mediterranean (Malik et al., 2020). A. sativum was tested against larvae of Anopheles stephensi and the $\mathrm{LC}_{50}$ values for hexane extract were $7.5 \mathrm{ppm}$ after 24 hours and $7.6 \mathrm{ppm}$ after 48 hours of exposure. Moreover, the $\mathrm{LC}_{90}$ values were $22.1 \mathrm{ppm}$ after 24 hours, and $15.4 \mathrm{ppm}$ after 48 hours of exposure (Shrankhla et al., 2012). 


\section{Malvaceae}

Sida acuta Burm. f. familiar as as Kurumthotti, is a weedy perennial shrubbery plant having a smooth bark (Sreedevi et al., 2009). The shrub is native to Central America and Mexico, although it has since spread throughout the tropics and subtropics (Karou et al., 2007). Ethanol fraction of $S$. acuta was found to have a significant action against $P$. falciparum at the $\mathrm{IC}_{50}$ value $4.37 \mu \mathrm{g} / \mathrm{ml}$ during a study of in vitro antimalarial test (Karou et al., 2003).

\section{Meliaceae}

Khaya grandifoliola C.DC. is a large-leaved evergreen tree that is also known as African mahogany, Benin mahogany or Senegal mahogany. Benin, Ghana, the Democratic Republic of the Congo, Sudan, Ivory Coast, Guinea, Togo, Nigeria, and Uganda are all home to it (Ojokuku et al., 2010). Antimalarial activity of $K$. grandifoliola stem and bark against $P$. berghei was investigated in mice by a group of researchers. Based on the study, the nhexane extract, the crude and purified fractions provided very good antimalarial activities with around $91 \%$ chemosuppression in vivo and $\mathrm{IC}_{50}$ values of $1.4 \mu \mathrm{g} / \mathrm{ml}$ (for multi-drug resistant clone of $P$. falciparum) and $0.84 \mu \mathrm{g} / \mathrm{ml}$ (for Nigerian $P$. falciparum isolates). (Agbedahunsi et al., 1998).

\section{Melianthaceae}

Bersama engleriana Gürke is a small to medium-sized tree that reaches a height of 6 to $9 \mathrm{~m}$, hardly surpassing $25 \mathrm{~m}$. It's often found throughout tropical Africa, Senegal to Zaire, Southern Africa as well as areas of favoring areas with more rainfall or evergreen woods (Watcho et al., 2014). The methanol extract of $B$. engleriana leaves displayed a prospective antiplasmodium effect, with an $\mathrm{IC}_{50}$ of $2.7 \mathrm{~g} / \mathrm{ml}$ against $P$. falciparum (Ngemenya et al., 2005).

\section{Menispermaceae}

Penianthus longifolius Miers is a tall shrub reaching up to $3-4.4 \mathrm{~m}$ which is native to the rain forests of Cameroon, Nigeria, Gabon, Equatorial Guinea, Central African Republic, Congo and Angola
(Tabekoueng et al., 2019). P. longifolius methanol extract had shown promising in vitro activity on two $P$. falciparum malarial clones designated as Indochina (W-2) and Sierra Leone (D-6) types with $\mathrm{IC}_{50}$ values of 350.066 and $284.377 \mathrm{ng} / \mathrm{ml}$, respectively (Tane et al., 2005).

\section{Myrtaceae}

Eucalyptus robusta Sm., popular as swamp mahogany, is a medium to large tree that typically grows of 20 to $30 \mathrm{~m}$ having a width of approximately $1 \mathrm{~m}$ (Boland et al., 2006). It is widely distributed to Australia's east coast. However, it has propagated itself in other nations and is said to cover a total area of 2.3 million hectares globally (Vuong et al., 2015). Aqueous extracts of E. robusta stem and bark demonstrated promising antimalarial activity by suppressing $P$. falciparum D10 strain with $\mathrm{IC}_{50}$ values of $10-20 \mu \mathrm{g} / \mathrm{ml}$ in parasite lactate dehydrogenase (pLDH) assay (Nundkumar and Ojewole, 2002).

\section{Poaceae}

Cymbopogon citratus (DC.) Stapf is a perennial aromatic plant native to southern India and Sri Lanka that grows up to $2 \mathrm{~m}$ tall with a $1.2 \mathrm{~m}$ wide and a thick clump. It is currently cultivated all over the world, especially in tropical, subtropical and Savannah countries (Machraoui et al., 2018). C. citratus has notable antimalarial efficacy, as evidenced by a study that found dosages of 200 to $1600 \mathrm{mg} / \mathrm{kg}$ dry powder of $C$. citratus suppressed parasitaemia against $P$. berghei ANKA strain by $91.89 \%$ to $96.61 \%$ (Chukwuocha et al., 2016). The essential oils from the extract of $C$. citratus leaves exhibited antimalarial activity against $P$. berghei in mice models with $\mathrm{IC}_{50}$ values ranging from 6 to $9.5 \mu \mathrm{g} / \mathrm{ml}$ (Tchoumbougnang et al., 2005).

\section{Piperaceae}

Peperomia vulcanica Baker \& C. H. Wright, an herbaceous plant, is seen around the world in subtropical and tropical areas, although they are most common in Central and Northern South America. The hexane and methylene chloride extracts of $P$. 
vulcanica demonstrated potential antimalarial activity with $\mathrm{IC}_{50}$ ranging from $0.89-3.23 \mu \mathrm{g} / \mathrm{ml}$ against $P$. falciparum (Ngemenya et al., 2015). Crude extract of $P$. vulcanica also demonstrated moderate antimalarial activity against $P$. falciparum (70\% inhibition by 40 $\mu \mathrm{g} / \mathrm{ml}$ crude extract) (Titanji et al., 2008; Ngemenya et al., 2004).

\section{Rubiaceae}

Morinda lucida Benth. is a medium-sized tree with short branches and dazzling leaves that reaches up to $15 \mathrm{~m}$ and is native to West and Central Africa (Chithambo et al., 2017). Ethanol extract of $M$. lucida had a good antimalarial efficacy against $P$. berghei while 400, 600 and $800 \mathrm{mg}$ doses inhibited $0.40 \pm 0.20,1.40 \pm 0.24$ and $1.20 \pm 0.58 \%$ parasitaemia on $5^{\text {th }}$ day of treatment in mice, respectively (Afolabi and Abejide, 2020).

Cinchona barks from Rubiaceae family are very popular sources of antimalarial therapeutics (Batista et al., 2009). They are found in mainly South America, particularly the Andes. It is also spread in Vietnam, India, Cameroon, Java, and a few more African and Asian nations (Raza et al., 2021). Quinine isolated from the barks is one of the very first antimalarial drugs used in early ages (Fernandez et al., 2008). It was discovered in 1820 by Pelletier and Caventou and used as lead antimalarial moiety for almost three centuries (Batista et al., 2009). Besides, quinine conjugates and its analogues can also serve promising antimalarial efficacies (Jones et al., 2015).

\section{Rutaceae}

Citrus sinensis (L.) Osbeck, a short evergreen tree of 7.5 to $15 \mathrm{~m}$ height, is widely cultivated in tropical, semi-tropical and some warm temperate regions. This tree is native to China, Southeast Asia, Malay Archipelago, New Caledonia and Australia (Etebu and Nwauzoma, 2014). Petroleum ether and methanol extract of ripe fruit rind of $C$. sinensis possessed antimalarial activity against $P$. falciparum FCK2 strain with $\mathrm{IC}_{50}$ values of 51.06 and $53.61 \mu \mathrm{g} / \mathrm{ml}$ respectively (Bhat et al., 2001). In another study, the crude extracts of $C$. sinensis peels were found active against Anopheles subpictus larva that causes malaria with $\mathrm{LC}_{50}$ of $58.25 \mathrm{ppm}$ and $\mathrm{LC}_{90}$ of $298.31 \mathrm{ppm}$ (El-Akhal et al., 2015).

\section{Scrophulariaceae}

Scoparia dulcis L., also known as sweet broom weed, is a branching perennial herb with wiry stems that may reach a height of one meter. It is extensively distributed throughout tropical and subtropical areas of India, West Indies, America, Brazil and Myanmar (Paul 2017). The ethyl acetate extract of $S$. dulcis inhibited the growth of $P$. falciparum with the $\mathrm{IC}_{50}$ value $19.5 \mu \mathrm{g} / \mathrm{ml}$ (Ngemenya et al., 2004).

\section{Simaroubaceae}

Quassia amara L. is a South American rain forest small tree, with a height of 2-6 m (Cachet et al., 2009). The hexane extract of $Q$. amara leaves exhibited promising antimalarial activity against $P$. berghei by suppressing the parasite density of $0.16 \pm 0.001 \%$ in the laboratory mouse. Methanol extract of $Q$. amara leaf also suppressed the parasite density of $0.05 \pm 0.03 \%$ at the dose of $200 \mathrm{mg} / \mathrm{kg}$ (Ajaiyeoba et al., 1999).

\section{Zingiberaceae}

Renealmia alpinia (Rottb.) Maas is an herb with gregarious and simple leaves that generally grows up to $2-6 \mathrm{~m}$ in height. This plant is native to tropical moist lowland rainforests but widely distributed in Mexico, Peru, Brazil, Antilles, French Guiana, Guyana, Suriname and Venezuela (Gómez-Betancur $\&$ Benjumea 2014). Aqueous rhizome extract of $R$. alpinia demonstrated antimalarial activity against $P$. falciparum chloroquine-resistant strain with an $\mathrm{IC}_{50}$ value of $10 \pm 1.4 \mu \mathrm{g} / \mathrm{ml}$ (Céline et al., 2009).

Renealmia thyrsoidea (Ruiz \& Pav.) Poepp. \& Endl. is a herbaceous perennial plant which produces clumps of erect stems around a height of $0.8-5 \mathrm{~m}$ (Maas 1977). The species is native to tropical America. Although it is widely spread in Bolivia, Guyana, Colombia, Ecuador, Nicaragua, Panama, Trinidad, Peru, Suriname and Tobago and Venezuela (Noriega et al., 2016). Based on previous research work, aqueous rhizome extract of $R$. thyrsoidea had 
shown antimalarial effect against $P$. falciparum chloroquine-resistant strain at the $\mathrm{IC}_{50}$ value of $6.8 \pm$ $1.5 \mu \mathrm{g} / \mathrm{ml}$ (Céline et al., 2009).

\section{Notable Bangladeshi plant families with antimalarial actions}

\section{Acanthaceae}

Andrographis paniculata (Burm.f.) Nees, popularly known as 'Kalmegh', is a branching annual plant that grows to $60-70 \mathrm{~cm}$ in height (Nyeem et al., 2017). It is widely common in Asian nations such as Bangladesh, India, Sri Lanka, Pakistan, Malaysia, and Indonesia (Nyeem et al., 2017). The methanol extract of $A$. paniculata whole plant inhibited the chloroquine-sensitive $P$. falciparum strain D10 with the $\mathrm{IC}_{50}$ value of $45.74 \mu \mathrm{g} / \mathrm{ml}$ and the resistant strain Gombak A with the $\mathrm{IC}_{50}$ of $65.06 \mu \mathrm{g} / \mathrm{ml}$ (Najila et al., 2002).

\section{Anacardiaceae}

Mangifera indica L. is a local Bangladeshi fruit producing tree and known as 'Aam' that grows as a medium to a large green tree that is generally 10 to $40 \mathrm{~m}$ in height (Parvez 2016). $M$. indica is grown in tropical regions around the world, including India, Thailand, China, Bangladesh, Malaysia and Indonesia (Pierson et al., 2014). M. indica aqueous extract exhibited $\mathrm{IC}_{50}$ of 18.11, 20.08, and $10.23 \mu \mathrm{g} / \mathrm{ml}$ against NF54, CamWT_C580Y, and FA08 parasite strains of $P$. falciparum, respectively (Jibira et al., 2020).

\section{Apocynaceae}

Rauvolfia serpentina (L.) Benth. ex Kurz, locally known as 'Sarpagandha' is a climbing evergreen perennial shrub (Chenniappan and Kadarkarai, 2010). The species is native to India, Bangladesh and other regions of Asia including Himalayas, Myanmar, Indonesia and Sri Lanka (Kumari et al., 2013). Based on a previous study, methylene chloride extract of $R$. serpentina bark exhibited notable antimalarial activity against chloroquine-resistant $P$. falciparum MRC-Pf-43 strain along with $\mathrm{IC}_{50}$ value of $8.32 \mu \mathrm{g} / \mathrm{ml}$ and 59\% inhibition (Chenniappan and Kadarkarai, 2010). In another study, $200 \mathrm{mg} / \mathrm{kg}$ of $R$. serpentina leaf ethanol extract showed antimalarial activity in $P$. berghei NK65 strain infected mice model with $84.14 \%$ chemo suppression, while $400 \mathrm{mg} / \mathrm{kg} R$. serpentina leaf hot water extract showed $82.53 \%$ chemo suppression (Omoya et al., 2019). In another in vivo study, a dose of $500 \mathrm{mg} / \mathrm{kg}$ of cyclohexane and methylene chloride extracts of $R$. serpentina root displayed moderate antiplasmodial activity against chloroquine-resistant $P$. berghei NK65 strain with $20 \%$ survival on $9^{\text {th }}$ day of post-infection (Samy and Kadarkari, 2011).

\section{Arecaceae}

Areca catechu L., commonly called 'Supari', is a $15-25 \mathrm{~m}$ tall megaphanerophyte with a single stem (Peng et al., 2015; Nath et al., 2011). It is also known as 'Areca nut' and widely consumed with Piper Betle leaf (locally known as 'Pan') in many Asian countries. It is commonly found in the tropical Pacific, Asian and few east African Countries (Garg et al., 2014). Butanol fraction of A. catechu nut extract exhibited remarkable antimalarial activity against $P$. falciparum showing the $\mathrm{IC}_{50}$ value of $18 \mu \mathrm{g} / \mathrm{ml}$ (Boniface et al., 2014).

\section{Fabaceae}

Erythrina variegata L. is a branched, deciduous medium-sized woody tree growing up to $25 \mathrm{~m}$ and is used by various tribes of Bangladesh (Rahmatullah et al., 2012). It is known as 'Mafang' in Bangladesh and also available in Taiwan, southern China, Philippines, Indonesia, Thailand, Myanmar, Malaysia, India, and Indian Ocean islands (Lim 2014; Rahmatullah et al., 2012). Methanol extract of the $E$. variegata leaves showed strong antimalarial activity over $P$. falciparum $\mathrm{K} 1$ strain with $\mathrm{IC}_{50}$ value of 6.8 $\mu \mathrm{g} / \mathrm{ml}$ (Herlina et al., 2011).

\section{Lamiaceae}

Ocimum gratissimum L. is a branching shrub that grows up to $1.9 \mathrm{~m}$ tall which is locally known as 'Ram Tulsi' in Bangladesh (Prabhu et al., 2009). The species is native to tropical regions, including India, West Africa, Savannah, coastal areas of Nigeria, Srilanka, Nepal, and Bangladesh (Prabhu et al., 
2009). Essential oils from the leaves of $O$. gratissimum were shown to be extremely potent over P. falciparum, with $\mathrm{IC}_{50}$ ranging from 6.9 to 14.9 $\mathrm{g} / \mathrm{ml}$ (Ngemenya et al., 2004).

\section{Meliaceae}

Azadirachta indica A.Juss., known as 'Neem' in Bangladesh, is a fast-growing evergreen tree having wide branches and may reach a height of $15-20 \mathrm{~m}$ (Maithani et al., 2011). Alongside Bangladesh, it can also grow in India and Myanmar though it can grow abundantly in tropical and subtropical areas (Maithani et al., 2011). Based on a previously conducted study, A. indica leaves extract had antiplasmodial activity against $P$. falciparum with the $\mathrm{LD}_{50}$ of $7.52 \mu \mathrm{g} / \mathrm{ml}, 6.76 \mu \mathrm{g} / \mathrm{ml}$, and $5.96 \mu \mathrm{g} / \mathrm{ml}$ for ethanol, methanol and acetone extracts respectively (Deshpande et al., 2014).

\section{Myrtaceae}

Syzygium cymosum (Lam.) DC., locally known as 'Khudijam' in Bangladesh, can grow up to a height of $15-20 \mathrm{~m}$ and has plain wide leaves (Hossainey et al., 2020). Tropical and subtropical regions including India, Singapore, Myanmar and Malacca are also home to this plant (Dhar et al., 2016). The crude methanol extract of $S$. cymosum leaves exhibited remarkable efficacy against chloroquine-sensitive 3D7, chloroquine-resistant Dd2 and mild efficacy against artemisinin-resistant IPC 4912 Mondulkiri strains of $P$. falciparum with the $\mathrm{IC}_{50}$ value of $6.28 \mu \mathrm{g} / \mathrm{ml}, 13.42 \mu \mathrm{g} / \mathrm{ml}$ and $17.47 \mu \mathrm{g} / \mathrm{ml}$, respectively (Hossainey et al., 2020).

\section{Conclusion}

Herbal plants are always great wellsprings of novel therapeutics which offer more efficacy and lesser side effects against various disease states compared to other synthetic drugs. In parallel, to treat malarial complications, medicinal plants and plant products have been also documented from the very old ages in different countries, cultures and tribes. Thus, to discover novel drug therapies against malaria and related complications, researchers can consider these herbal plants although further studies are still recommended to figure out the exact phytochemicals responsible for displayed antimalarial actions and their accurate mechanism of actions.

\section{Funding}

This research did not receive any specific grant from funding agencies in the public, commercial, or non-profit sectors.

\section{Authors' contributions}

SA and TBK conceptualized and designed the review work. ATO, AZ, HH and TBK gathered the previous works. ATO, SA, AZ and $\mathrm{HH}$ wrote the manuscript. TS and MAI critically reviewed the manuscript. SA edited and drafted the final manuscript and supervised the total work.

\section{Declarations}

The manuscript was read and approved for submission by all concerned authors. No part of the manuscript has been previously published, and no part of it is currently being considered for publication in any journal.

\section{Conflict of interest}

The authors state that they have no conflicting interests that could have appeared to influence the work reported in this paper.

\section{References}

Adjanohoun, J.E., Aboubakar, N., Dramane, K., Ebot, M.E., Ekpere, J.A., Enow-Orock, E.G., Focho, D., Gbile, Z.O., Kamanyi, A., Kamsu-Kom, J. and Keita, A. 1996. Traditional medicine and pharmacopoeia: contribution to ethnobotanical and floristic studies in Cameroon. Afr. Stud. Monogr. 25, 1-27.

Afolabi, O.J. and Abejide, A.E. 2020. Antiplasmodial activities of Morinda lucida (Benth) and Alstonia boonei (De wild) in mice infected with Plasmodium berghei. Bull. Natl. Res. Cent. 44, 1-6. DOI: https://doi.org/10.1186/s42269-020-00342-8

Agbaje, E.O. and Onabanjo, A.O. 1991. The effects of extracts of Enantia chlorantha in malaria. Ann. Rev. Trop. Med. Parasitol. 85, 585-590. DOI: https://doi.org/10.1080/00034983.1991.11812613 
Agbedahunsi, J.M., Elujoba, A.A., Makinde, J.M. and Oduda, A.M.J. 1998. Antimalarial activity of Khaya grandifoliola stem-bark. Pharm. Biol. 36, 8-12. DOI: https://doi.org/10.1076/phbi.36.1.8.4613

Ahmed, H. 2017. A phyto pharmacological review on a medicinal plant: Holarrhena floribunda. J. Med. Plants Stud. 5, 26-29.

Ajaiyeoba, E.O., Abalogu, U.I., Krebs, H.C. and Oduola, A.M.J. 1999. In vivo antimalarial activities of Quassia amara and Quassia undulata plant extracts in mice. $J$. Ethnopharmacol. 67, 321-325. DOI: https://doi.org/ 10.1016/S0378-8741(99)00073-2

Ajaiyeoba, E.O., Ogbole, O.O., Abiodun, O.O., Ashidi, J.S., Houghton, P.J. and Wright, C.W. 2013. Cajachalcone: An antimalarial compound from Cajanus cajan leaf extract. J. Parasitol. Res. 2013. DOI: https://doi.org/10.1155/2013/703781

Ajao, A.A. and Moteetee, A.N. 2017. Tithonia diversifolia (Hemsl) A. Gray.(Asteraceae: Heliantheae), an invasive plant of significant ethnopharmacological importance: A review. S. Afr. J. Bot. 113, 396-403. DOI: https://doi.org/10.1016/j.sajb.2017.09.017

Alam, S., Emon, N.U., Shahriar, S., Richi, F.T., Haque, M.R., Islam, M.N., Sakib, S.A. and Ganguly, A. 2020. Pharmacological and computer-aided studies provide new insights into Millettia peguensis Ali (Fabaceae). Saudi Pharm. J. 28, 1777-1790. DOI: https://doi.org/10.1016/j.jsps.2020.11.004

Alam, S., Rashid, M.A., Sarker, M.M.R., Emon, N.U., Arman, M., Mohamed, I.N. and Haque, M.R. 2021. Antidiarrheal, antimicrobial and antioxidant potentials of methanol extract of Colocasia gigantea Hook. f. leaves: evidenced from in vivo and in vitro studies along with computer-aided approaches. BMC Complement. Med. Ther. 21, 1-12. DOI: https://doi.org/10.1186/s12906-021-03290-6

Alebie, G., Urga, B. and Worku, A. 2017. Systematic review on traditional medicinal plants used for the treatment of malaria in Ethiopia: trends and perspectives. Malar. J. 16, 1-13. DOI: https://doi.org/10.1186/s12936-017-1953-2

Amusan, O.O., Adesogan, E.K. and Makinde, J.M. 1996. Antimalarial active principles of Spathodea campanulata stem bark. Phytother. Res. 10, 692-693. DOI: $\quad$ https://doi.org/10.1002/(SICI)1099-1573 (199612)10:8<692::AID-PTR928>3.0.CO;2-O

Ayele, D.G., Zewotir, T.T. and Mwambi, H.G. 2012. Prevalence and risk factors of malaria in Ethiopia. Malar. J. 11, 195. DOI: https://doi.org/ 10.1186/1475-2875-11-195
Azebaze, A.G.B., Dongmo, A.B., Meyer, M., Ouahouo, B.M.W., Valentin, A., Laure Nguemfo, E., Nkengfack, A.E. and Vierling, W. 2007. Antimalarial and vasorelaxant constituents of the leaves of Allanblackia monticola (Guttiferae). Ann. Rev. Trop. Med. Parasitol. 101, 23-30. DOI: https://doi.org/ 10.1179/136485907X157022

Banzouzi, J.T., Prado, R., Menan, H., Valentin, A., Roumestan, C., Mallie, M., Pelissier, Y. and Blache, Y. 2002. In vitro antiplasmodial activity of extracts of Alchornea cordifolia and identification of an active constituent: ellagic acid. J. Ethnopharmacol. 81, 399401. DOI: https://doi.org/10.1016/S0378-8741(02) 00121-6

Batista, R., De Jesus Silva Júnior, A. and De Oliveira, A.B. 2009. Plant-derived antimalarial agents: new leads and efficient phytomedicines. Part II. Non-alkaloidal natural products. Molecules 14, 3037-3072.

Bekker, M., Bekker, R. and Brandt, V.E. 2006. Two flavonoid glycosides and a miscellaneous flavan from the bark of Guibourtia coleosperma. Phytochemistry, 67, 818-823. DOI: https://doi.org/10.1016/j. phytochem.2006.01.015

Bhat, G.P. and Surolia, N. 2001. In vitro antimalarial activity of extracts of three plants used in the traditional medicine of India. Am. J. Trop. Med. Hyg. 65, 304-308. DOI: https://doi.org/ 10.4269/ajtmh. 2001.65.304

Boland, D.J., Brooker, M.I.H., Chippendale, G.M., Hall, N., Hyland, B.P.M., Johnston, R.D., Kleinig, D.A., McDonald, M.W. and Turner, J.D. eds. 2006. Forest trees of Australia. CSIRO publishing.

Boniface, P., Verma, S.K., Cheema, H.S., Darokar, M.P. and Pal, A. 2014. Evaluation of antimalarial and antimicrobial activites of extract and fractions from Areca catechu. Int. J. Infect. Dis 21, 228-229. DOI: https://doi.org/10.1016/j.ijid.2014.03.897

Bose, A., Lategan, C.A., Smith, P.J. and Gupta, J.K. 2010. Studies on in vitro antiplasmodial activity of Cleome rutidosperma. Acta Pol. Pharm. 67, 315-318.

Boyom, F.F., Fokou, P.V.T., Yamthe, L.R.T., Mfopa, A.N., Kemgne, E.M., Mbacham, W.F., Tsamo, E., Zollo, P.H.A., Gut, J. and Rosenthal, P.J. 2011. Potent antiplasmodial extracts from Cameroonian Annonaceae. J. Ethnopharmacol. 134, 717-724. DOI: https://doi.org/10.1016/j.jep.2011.01.020

Cachet, N., Hoakwie, F., Bertani, S., Bourdy, G., Deharo, E., Stien, D., Houel, E., Gornitzka, H., Fillaux, J., Chevalley, S. and Valentin, A. 2009. Antimalarial activity of simalikalactone $\mathrm{E}$, a new quassinoid from Quassia amara L.(Simaroubaceae). Antimicrob. Agents Chemother. 53, 4393-4398. DOI: https://doi/10.1128/AAC.00951-09 
Céline, V., Adriana, P., Eric, D., Joaquina, A.C., Yannick, E., Augusto, L.F., Rosario, R., Dionicia, G., Michel, S., Denis, C. and Geneviève, B. 2009. Medicinal plants from the Yanesha (Peru): Evaluation of the leishmanicidal and antimalarial activity of selected extracts. J. Ethnopharmacol 123, 413-422. DOI: https://doi.org/10.1016/j.jep.2009.03.041

Chenniappan, K. and Kadarkarai, M. 2010. In vitro antimalarial activity of traditionally used Western Ghats plants from India and their interactions with chloroquine against chloroquine-resistant Plasmodium falciparum. Parasitol. Res. 107, 1351-1364. DOI: https://doi.org/10.1007/s00436-010-2005-9

Chithambo, B., Noundou, X.S. and Krause, R.W. 2017. Anti-malarial synergy of secondary metabolites from Morinda lucida Benth. J. Ethnopharmacol. 199, 9196. DOI: https://doi.org/10.1016/j.jep.2017.01.051

Chukwuocha, U.M., Fernández-Rivera, O. and LegorretaHerrera, M. 2016. Exploring the antimalarial potential of whole Cymbopogon citratus plant therapy. J. Ethnopharmacol. 193, 517-523. DOI: https://doi.org/10.1016/j.jep.2016.09.056

Coria-Téllez, A.V., Montalvo-Gónzalez, E., Yahia, E.M. and Obledo-Vázquez, E.N. 2018. Annona muricata: A comprehensive review on its traditional medicinal uses, phytochemicals, pharmacological activities, mechanisms of action and toxicity. Arab. J. Chem. 11, 662-691.

DOI: https://doi.org/10.1016/j.arabjc.2016.01.004

Cynthia, N.B. 2018. Antiplasmodial activity and acute oral toxicity of Rauvolfia vomitoria leaves extracts. IJPR, 8, 56-62. DOI: https://doi.org/10.7439/ijpr

Das, S. 2012. Artemisia annua (Qinghao): a pharmacological review. Int. J. Pharm. Sci. Res. 3, 4573-4577.

Debela, M.B., Kahsay, A.B. and Mokonnon, T.M. 2018. Malaria outbreak and contracting factors in Afar region, Ethiopia, 2016. J. Public Health Epidemiol. 10, 233-240. DOI: https://doi.org/10.5897 /JPHE2018.1000

Deshpande, P.K., Gothalwal, R. and Pathak, A.K. 2014. Phytochemical analysis and evaluation of antimalarial activity of Azadirachta indica. Pharm. Innov. 3, 1216.

Dhar, K.S., Wahed, T.B., Hasan, A.N. and Wahed, S.B. 2016. In vitro antioxidant activities and cytotoxicity study of the methanolic extract of barks of Syzygium cymosum. Int. J. Pharm. Sci. Res. 7, 1021-1025. DOI: http://dx.doi.org/10.13040/IJPSR.0975-8232.7

(3). $1021-25$
Dobson, M.J. 1994. Malaria in England: a geographical and historical perspective. Parassitologia, 36, 35-60.

du Preez, I., Louw, S. and Mumbengegwi, D.R. 2020. Chemical Composition and Inhibitory Effects of Guibourtia coleosperma against Plasmodium Parasites In Vitro. In African Natural Plant Products, Volume III: Discoveries and Innovations in Chemistry, Bioactivity, and Applications, 153-170. American Chemical Society. DOI: https://doi.org/10.1021/bk2020-1361.ch007

El-Akhal, F., Lalami, A.E.O. and Guemmouh, R. 2015. Larvicidal activity of essential oils of Citrus sinensis and Citrus aurantium (Rutaceae) cultivated in Morocco against the malaria vector Anopheles labranchiae (Diptera: Culicidae). Asian Pac. J. Trop. Med. 5, 458-462. DOI: https://doi.org/10.1016/S22221808(15)60815-5

Emon, N.U., Alam, S., Rudra, S., Riya, S.R., Paul, A., Hossen, S.M., Kulsum, U. and Ganguly, A. 2021. Antidepressant, anxiolytic, antipyretic, and thrombolytic profiling of methanol extract of the aerial part of Piper nigrum: In vivo, in vitro, and in silico approaches. Food Sci. Nutr. 9, 833-846. DOI: https://doi.org/10.1002/fsn3.2047

Emon, N.U., Kaiser, M., Islam, M., Kabir, M.F.I., Jamir, M., Uddin, M.A.J. and Islam, M.N. 2020. Anxiolytic and thrombolytic investigation of methanol extract of Piper nigrum L. fruits and Sesamum indicum L. seeds. J. Adv. Biotechnol. Exp. Ther. 3, 158-164. DOI: https://doi.org/10.5455/jabet.2020.d121

Enechi, O.C., Okagu, I.U., Amah, C.C., Ononiwu, P.C., Igwe, J.F. and Onyekaozulu, C.R. 2021. Flavonoidrich extract of Buchholzia coriacea Engl. seeds reverses Plasmodium berghei-modified haematological and biochemical status in mice. Scientific African, 12, e00748. DOI: https://doi.org/10.1016/j.sciaf.2021.e00748

Etebu, E. and Nwauzoma, A.B. 2014. A review on sweet orange (Citrus sinensis L Osbeck): health, diseases and management. Am. J. Trop. Med. Hyg. 2, 33-70.

Fernandez, L.S., Jobling, M.F., Andrews, K.T. and Avery, V.M. 2008. Antimalarial activity of natural product extracts from Papua New Guinean and Australian plants against Plasmodium falciparum. Phytother. Res. 22, 1409-1412. DOI: https://doi.org/10.1002/ptr.2510

Garg, A., Chaturvedi, P. and Gupta, P.C. 2014. A review of the systemic adverse effects of areca nut or betel nut. Indian J Med Paediatr Oncol. 35, 3-9. DOI: 10.4103/0971-5851.133702 
Ghosh, P., Chatterjee, S., Das, P., Karmakar, S. and Mahapatra, S. 2019. Natural habitat, phytochemistry and pharmacological properties of a medicinal weedCleome rutidosperma DC.(Cleomaceae): A comprehensive review. Int. J. Pharm. Sci. Res. 10, 1605-1612. DOI: http://dx.doi.org/10.13040/ IJPSR.0975-8232.10(4).1605-12

Gómez-Betancur, I. and Benjumea, D. 2014. Traditional use of the genus Renealmia and Renealmia alpinia (Rottb.) Maas (Zingiberaceae)-a review in the treatment of snakebites. Asian Pac. J. Trop. Med. 7, 574-S582. DOI: https://doi.org/10.1016/S19957645(14)60292-3

Grabias, B. and Kumar, S. 2016. Adverse neuropsychiatric effects of antimalarial drugs. Expert Opin. Drug Saf. 15, 903-910. DOI: https://doi.org/10.1080/14740338. 2016.1175428

Greenwood, B. and Mutabingwa, T. 2002. Malaria in 2002. Nature 415, 670-672. DOI: https://doi.org/ $10.1038 / 415670 \mathrm{a}$

Haque, U., Overgaard, H.J., Clements, A.C., Norris, D.E., Islam, N., Karim, J., Roy, S., Haque, W., Kabir, M., Smith, D.L. and Glass, G.E. 2014. Malaria burden and control in Bangladesh and prospects for elimination: an epidemiological and economic assessment. Lancet Glob. Health 2, e98-e105. DOI: https://doi.org/ 10.1016/S2214-109X(13)70176-1

Hempelmann, E. and Krafts, K. 2013. Bad air, amulets and mosquitoes: 2,000 years of changing perspectives on malaria. Malar. J. 12, 1-14. DOI: https://doi.org/ 10.1186/1475-2875-12-232

Herlina, T., Supratman, U., Urbanas, A., Sutardjo, S., Abdullah, N.R. and Hayashi, H. 2011. Triterpenoid Pentacyclic Antimalarial Activity from the Leaves of Erythrina variegata. J. Ilmu Dasar 12, 161-166.

Hoekou, Y.P., Tchacondo, T., Karou, S.D., Yerbanga, R.S., Achoribo, E., Da, O., Atakpama, W. and Batawila, K. 2017. Therapeutic potentials of ethanolic extract of leaves of Holarrhena floribunda (G. Don) Dur. and schinz (apocynaceae). Afr. J. Tradit. Complement. Altern. Med. 14, 227-233. DOI: https://10.21010/ ajtcam.v14i2.24

Hossainey, M.R.H., Sazed, S.A., Nima, M.K., Rahman, M.S., Ashraf, T., Chowdhury, A.A., Rashid, M.A., Haque, R. and Alam, M.S. 2020. Investigation of antimalarial activity and cytotoxicity profiling of a Bangladeshi plant Syzygium cymosum. J. Infect. Dev. Ctries. 14, 924-928. DOI: https://doi.org/10.3855/ jidc. 12740
Jibira, Y., Cudjoe, E., Tei-Maya, F.M., Ayensu, B. and Amoah, L.E. 2020. The Effectiveness of Varying Combination Ratios of $A$. cordifolia and $M$. indica against Field and Laboratory Strains of $P$. falciparum In Vitro. J. Parasitol. 2020. DOI: https://doi. org/10.1155/2020/8836771

Jones, R.A., Panda, S.S. and Hall, C.D. 2015. Quinine conjugates and quinine analogues as potential antimalarial agents. Eur. J. Med. Chem. 97,335-355. DOI: https://doi.org/10.1016/j.ejmech.2015.02.002

Karou, D., Dicko, M.H., Sanon, S., Simpore, J. and Traore, A.S. 2003. Antimalarial activity of Sida acuta Burm. f.(Malvaceae) and Pterocarpus erinaceus Poir.(Fabaceae). J. ethnopharmacol. 89, 291-294. DOI: https://doi.org/10.1016/j.jep.2003.09.010

Karou, S.D., Nadembega, W.M., Ilboudo, D.P., Ouermi, D., Gbeassor, M., De Souza, C. and Simpore, J., 2007. Sida acuta Burm. f.: a medicinal plant with numerous potencies. Afr. J. Biotechnol. 6, 2953-2959. DOI: https://10.5897/AJB2007.000-2463

Kong, Y., Fu, Y.J., Zu, Y.G., Chang, F.R., Chen, Y.H., Liu, X.L., Stelten, J. and Schiebel, H.M. 2010. Cajanuslactone, a new coumarin with anti-bacterial activity from pigeon pea [Cajanus cajan (L.) Millsp.] leaves. Food chem. 121, 1150-1155. DOI: https://doi.org/10.1016/j.foodchem.2010.01.062

Kuete, V., Tabopda, T.K., Ngameni, B., Nana, F., Tshikalange, T.E. and Ngadjui, B.T. 2010. Antimycobacterial, antibacterial and antifungal activities of Terminalia superba (Combretaceae). S. Afr. J. Bot. 76, 125-131. DOI: https://doi.org/10.1016/ j.sajb.2009.09.009

Kumar, S., Malhotra, R. and Kumar, D. 2010. Euphorbia hirta: Its chemistry, traditional and medicinal uses, and pharmacological activities. Pharmacogn. Rev. 4, 58-61. DOI: https://doi.org/10.4103/0973-7847.65327

Kumari, R., Rathi, B., Rani, A. and Bhatnagar, S. 2013. Rauvolfia serpentina L. Benth. ex Kurz.: phytochemical, pharmacological and therapeutic aspects. Int. J. Pharm. Sci. Rev. Res. 23, 348-355.

Lim, T.K. 2014. Erythrina variegata. In Edible Medicinal And Non-Medicinal Plants (788-805). Springer, Dordrecht.

Liu, Y., Murakami, N., Ji, H., Abreu, P. and Zhang, S. 2007. Antimalarial Flavonol Glycosides from Euphorbia hirta. Pharm. Biol. 45, 278-281. DOI: https://doi.org/10.1080/13880200701214748

Maas, P.J. 1977. Renealmia (ZingiberaceaeZingiberoideae) Costoideae (Additions) (Zingiberaceae). Flora Neotrop. 18, 1-218. 
Machraoui, M., Kthiri, Z., Ben Jabeur, M. and Hamada, W. 2018. Ethnobotanical and phytopharmacological notes on Cymbopogon citratus (DC.) Stapf. J. New Sci. 55, 3642-3652.

Maithani, A., Parcha, V., Pant, G., Dhulia, I. and Kumar, D. 2011. Azadirachta indica (neem) leaf: A review. J. Pharm. Res. 4, 1824-1827.

Malik, M.Q., Mujib, A., Gulzar, B., Zafar, N., Syeed, R., Mamgain, J. and Ejaz, B. 2020. Genome size analysis of field grown and somatic embryo regenerated plants in Allium sativum L. J. Appl. Genet. 61, 25-35. DOI: https://doi.org/10.1007/s13353-019-00536-5

Mbouna, C.D., Kouipou, R.M., Keumoe, R., Tchokouaha, L.R., Fokou, P.V., Tali, B.M., Sahal, D. and Boyom, F.F. 2018. Potent antiplasmodial extracts and fractions from Terminalia mantaly and Terminalia superba. Malar. J. 17, 1-9. DOI: https://doi.org/10.1186/ s12936-018-2298-1

Mojarrab, M., Shiravand, A., Delazar, A. and Heshmati Afshar, F. 2014. Evaluation of in vitro antimalarial activity of different extracts of Artemisia aucheri Boiss. and A. armeniaca Lam. and fractions of the most potent extracts. Sci. World J. 2014. DOI: https://doi.org/10.1155/2014/825370

Muthaura, C.N., Rukunga, G.M., Chhabra, S.C., Mungai, G.M. and Njagi, E.N.M. 2007. Traditional phytotherapy of some remedies used in treatment of malaria in Meru district of Kenya. S. Afr. J. Bot. 73, 402-411. DOI: https://doi.org/10.1016/j.sajb. 2007.03.004

Najila, M.S., Rain, A.N., Kamel, A.M., Zahir, S.S., Khozirah, S., Hakim, S.L., Zakiah, I. and Azizol, A.K. 2002. The screening of extracts from Goniothalamus scortechinii, Aralidium pinnatifidum and Andrographis paniculata for anti-malarial activity using the lactate dehydrogenase assay. $J$. Ethnopharmacol. 82, 239-242. DOI: https://doi. org/10.1016/S0378-8741(02)00183-6

Nandi, R., Hossain, A. and Anwar, N. 2019. Cultivation and economic prospects of Betel Nut (Areca catechu Linn.) and Coconut (Cocos nucifera Linn.) in rural economy: A case study from southeastern region of Bangladesh. Environ. Earth Ecology 3, 24-34. DOI: https://doi.org/10.24051/eee/96310

Nath, T.K., Inoue, M., Pradhan, F.E. and Kabir, M.A. 2011. Indigenous practices and socio-economics of Areca catechu L. and Piper betel L. based innovative agroforestry in northern rural Bangladesh. For. Trees Livelihoods 20, 175-190. DOI: https://doi.org/10.1080/ 14728028.2011.9756705
Ngemenya, M., Tilanji, V., Akam, T., Yong, J., Tane, P., Fanso-Free, S. and Berzins, K. 2005. Antiplasmodial activity and toxicity of extracts and products from selected medicinal plant used in Cameroon. Acta Trop. 96, 1-506.

Ngemenya, M.N., Metuge, H.M., Mbah, J.A., Zofou, D., Babiaka, S.B. and Titanji, V.P. 2015. Isolation of natural product hits from Peperomia species with synergistic activity against resistant Plasmodium falciparum strains. Eur. J. Med. Chem. 5, 77-87. DOI: https://doi.org/10.9734/EJMP/2015/13158

Ngemenya, M.N., Tane, P., Berzins, K. and Titanji, V.P.K. 2004, December. Antiplasmodial activity of some medicinal plants used in Cameroon: preliminary toxicity studies of highly active extracts. In XIth annual conference of the Cameroon Bioscience Society, 16-18.

Ngouela, S., Tsamo, E., Sondengam, B.L. and Connolly, J.D. 1991. Spathodol, a new polyhydroxysterol from the leaves of Spathodea campanulata. J. Nat. Prod. 54, 873-876. DOI: https://doi.org/10.1021/ np50075a023

Nguta, J.M., Mbaria, J.M., Gakuya, D.W., Gathumbi, P.K. and Kiama, S.G. 2010. Antimalarial herbal remedies of Msambweni, Kenya. J. Ethnopharmacol. 128, 424432. DOI: https://doi.org/10.1016/j.jep.2010.01.033

Noriega, P.F., Paredes, E.A., Mosquera, T.D., Díaz, E.E., Lueckhoff, A., Basantes, J.E. and Trujillo, A.L. 2016. Chemical Composition antimicrobial and free radical scavenging activity of essential oil from leaves of Renealmia thyrsoidea (Ruiz Pav.) Poepp. Endl. J. Med. Plant Res. 10, 553-558. DOI: https://doi.org/10.5897/JMPR2016.6217

Nundkumar, N. and Ojewole, J.A.O. 2002. Studies on the antiplasmodial properties of some South African medicinal plants used as antimalarial remedies in Zulu folk medicine. Methods Find. Exp. Clin. Pharmacol. 24, 397-401. DOI: https://doi.org/ 10.1358/mf.2002.24.7.696540

Nyeem, M.A.B., Mannan, M.A., Nuruzzaman, M., Kamrujjaman, K.M. and Das, S.K. 2017. Indigenous king of bitter (Andrographis paniculata): A review. $J$. Med. Plants Stud. 5, 318-324.

Ogbuehi, I.H., Ebong, O.O., Asuquo, E.O. and Nwauche, C.A. 2013. Evaluation of the antiplasmodial activity of the methanolic root extracts of Anthocleista nobilis G. Don, Nauclea latifolia Smith and Napoleona imperialis P. Beauv. British J. Pharmacol. Toxicol. 5, 75-82. 
Ojokuku, S.A., Okunowo, W.O. and Apena, A. 2010. Evaluation of the chemical composition of Khaya grandifoliola and Ficus capensis. J. Med. Plant Res. 4, 1126-1129. DOI: https://doi.org/10.5897/JMPR10.220

Olatokunboh, A.O., Kayode, Y.O. and Adeola, O.K. 2009. Anticonvulsant activity of Rauvolfia vomitoria (Afzel). Afr. J. Pharmacy Pharmacol. 3, 319-322. DOI: https://doi.org/10.5897/AJPP.9000044

Omoya, F.O., Falusi, O.A. and Ogundare, A.O. 2019. In vivo Antimalarial Activity and Toxicological Effects of Ethanolic and Hot Water Extracts of Rauwolfia serpentina leaf in mice infected with Chloroquinesensitive Plasmodium berghei. J. Microbiol. Antimicrob.Agents 3, 3-12.

Onguéné, P.A., Ntie-Kang, F., Lifongo, L.L., Ndom, J.C., Sippl, W. and Mbaze, L.M.A. 2013. The potential of anti-malarial compounds derived from African medicinal plants. Part I: A pharmacological evaluation of alkaloids and terpenoids. Malar. J. 12, 1-26. DOI: https://doi.org/10.1186/1475-2875-12-449

Osadebe, P.O. and Okoye, F.B.C. 2003. Anti-inflammatory effects of crude methanolic extract and fractions of Alchornea cordifolia leaves. J. Ethnopharmacol. 89, 19-24. DOI: https://doi.org/10.1016/S0378-8741(03) 00195-8

Oyewole, I.O., Adeoye, G.O., Anyasor, G.N. and Obansa, J.A. 2008. Anti-malarial and repellent activities of Tithonia diversifolia (Hemsl.) leaf extracts. J. Med. Plant Res. 2, 171-175. DOI: https://doi.org/10.5897/ JMPR.9000104

Parvez, G.M. 2016. Pharmacological activities of mango (Mangifera Indica): A review. Res. Rev.: J. Pharmacogn. Phytochem. 5, 1-7.

Paul, M. 2017. Scoparia dulcis: A review on its phytochemical and pharmacological profile. Innoriginal: Int. J. Sci. 4, 18-22.

Peng, W., Liu, Y.J., Wu, N., Sun, T., He, X.Y., Gao, Y.X. and Wu, C.J. 2015. Areca catechu L.(Arecaceae): A review of its traditional uses, botany, phytochemistry, pharmacology and toxicology. J. Ethnopharmacol. 164, 340-356. DOI: https://doi.org/10.1016/ j.jep. 2015.02.010

Pierson, J.T., Monteith, G.R., Roberts-Thomson, S.J., Dietzgen, R.G., Gidley, M.J. and Shaw, P.N. 2014. Phytochemical extraction, characterisation and comparative distribution across four mango (Mangifera indica L.) fruit varieties. Food chem. 149, 253-263. DOI: https://doi.org/10.1016/j.foodchem. 2013.10.108.
PMI, 2008. Malaria Operational Plan (MOP) Ethiopia. Available at: https://www.pmi.gov/docs/defaultsource/default-document-library/malaria-operationalplans/fy08/ethiopia_mop-fy08.pdf?sfvrsn $=6$ (Accessed on: 17 April,2021).

Poinar, G. 2005. Plasmodium dominicana n. sp. (Plasmodiidae: Haemospororida) from Tertiary Dominican amber. Syst. Parasitol. 61, 47-52. DOI: https://doi.org/10.1007/s11230-004-6354-6

Prabhu, K.S., Lobo, R., Shirwaikar, A.A. and Shirwaikar, A. 2009. Ocimum gratissimum: A review of its chemical, pharmacological and ethnomedicinal properties. Open Complement. Med. J. 1, 1-15. DOI: https://doi.org/10.2174/1876391X00901010001

Rahmatullah, M., Hossan, S., Khatun, A., Seraj, S. and Jahan, R. 2012. Medicinal plants used by various tribes of Bangladesh for treatment of malaria. Malar. Res. $\quad$ Treat. $2012 . \quad$ DOI: https://doi.org/10.1155/2012/371798

Rajan, A. and Bagai, U. 2012. Evaluation of antiplasmodial efficacy and safety of Cinchona officinalis against lethal murine malaria parasite. Am. J. Homeopathic Med. 105, 76-83.

Rasoanaivo, P., Wright, C.W., Willcox, M.L. and Gilbert, B. 2011. Whole plant extracts versus single compounds for the treatment of malaria: synergy and positive interactions. Malar. J. 10, 1-12. DOI: https://doi.org/10.1186/1475-2875-10-S1-S4

Raza, M.A., Rehman, F.U., Anwar, S., Zahra, A., Rehman, A., Rashid, E., Kalsoom, M. and Ilahi, H. 2021. The medicinal and aromatic activities of cinchona: a review. Asian J. Adv. Agric. Res. 8, 42-45.

Sajib Rudra, M., Sawon, S.U., Emon, N.U., Alam, S., Tareq, S.M., Islam, M.N. and Shakil, M. 2020. Biological investigations of the methanol extract of Tetrastigma leucostaphylum (Dennst.) Alston ex Mabb.(Vitaceae): In vivo and in vitro approach. $J$. Adv. Biotechnol. Exp. Ther. 3, 216-224. DOI: https://doi.org/10.5455/jabet.2020.d127

Samy, K. and Kadarkari, M. 2011. Antimalarial activity of traditionally used Western Ghats plants from India and their interactions with chloroquine against chloroquine-tolerant Plasmodium berghei. VectorBorne and Zoonotic Dis. 11, 259-268. DOI: https://doi.org/10.1089/vbz.2009.0208

Santhosh, S.B., Yuvarajan, R. and Natarajan, D. 2015. Annona muricata leaf extract-mediated silver nanoparticles synthesis and its larvicidal potential against dengue, malaria and filariasis vector. Parasitol. Res. 114, 3087-3096. DOI: https://doi.org/10.1007/s00436-015-4511-2 
Sendl, A. 1995. Allium sativum and Allium ursinum: Part 1 Chemistry, analysis, history, botany. Phytomedicine. 1, 323-339. DOI: https://doi.org/10.1016/S09447113(11)80011-5

Shrankhla, B.S., Sharma, P., Mohan, L. and Srivastava, C.N. 2012. Relative larvicidal potential of Pseudocalymma alliaceum and Allium sativum against malaria vector, Anopheles stephensi (Liston). Eur. Mosq. Bull. 30, 83-90.

Sreedevi, C.D., Latha, P.G., Ancy, P., Suja, S.R., Shyamal, S., Shine, V.J., Sini, S., Anuja, G.I. and Rajasekharan, S., 2009. Hepatoprotective studies on Sida acuta Burm. f. J. ethnopharmacol. 124, 171-175. DOI: https://doi.org/10.1016/j.jep.2009.04.055

Tabekoueng, G.B., Akak, C.M., Langat, M.K., Azebaze, A.G.B., Waffo, A.F.K., Mulholland, D.A. and Vardamides, J.C. 2019. The chemical constituents of Penianthus longifolius Miers. Phytochem. Lett. 30, 103-106. DOI: https://doi.org/10.1016/j.phytol. 2019.01.026

Tajuddeen, N. and Van Heerden, F.R., 2019. Antiplasmodial natural products: an update. Malar. J. 18, 1-62. DOI: https://doi.org/10.1186/s12936-0193026-1

Tane, P., Okunji, C.O., Tchimene, M.K., Iwu, M.M. and Schuster, B.M. 2005. Antimalarial natural products from some Cameroonian medicinal plants. $j$. Cameroon Acad. Sci. 5, 65-76.

Tcheghebe, O.T., Tatong, F.N. and Seukep, A.J. 2016. Traditional uses, phytochemical and pharmacological profiles, and toxicity of Enantia chlorantha (Oliver): An overview. Edorium J. Med. 3, 12-18. DOI: https://doi.org/10.5348/M05-2016-4-RA-2

Tchoumbougnang F, Amvam Zollo PH, Dagne E, Mekonnen Y 2005. In vivo antimalarial activity of essential oils from Cymbopogon citratus and Ocimum gratissimum on mice infected with Plasmodium berghei. Planta Med. 71, 20-23. DOI: https://doi.org/10.1055/s-2005-837745

Titanji, V.P., Zofou, D. and Ngemenya, M.N. 2008. The antimalarial potential of medicinal plants used for the treatment of malaria in Cameroonian folk medicine. Afr. J. Tradit. Complement. Altern. Med. 5, 302-321.

Uzor, P.F., Prasasty, V.D. and Agubata, C.O. 2020. Natural Products as Sources of Antimalarial Drugs. Evid-base. Complement. Alternat. Med. 2020. DOI: https://doi. org/10.1155/2020/9385125
Vuong, Q.V., Hirun, S., Chuen, T.L., Goldsmith, C.D., Munro, B., Bowyer, M.C., Chalmers, A.C., Sakoff, J.A., Phillips, P.A. and Scarlett, C.J. 2015. Physicochemical, antioxidant and anti-cancer activity of a Eucalyptus robusta (Sm.) leaf aqueous extract. Ind. Crops. Prod. 64, 167-174. DOI: https://doi.org /10.1016/j.indcrop.2014.10.061

Watcho, P., Mbiakop, U.C., Jeugo, H.G.A., Wankeu, M., Nguelefack, T.B., Carro-Juarez, M. and Kamanyi, A. 2014. Delay of ejaculation induced by Bersama engleriana in nicotinamide/streptozotocin-induced type 2 diabetic rats. Asian Pac. J. Trop. Med. 7, S603S609. DOI: https://doi.org/10.1016/S1995-7645(14) 60296-0

WHO, 2015. World Malaria Report. Available at: https://www.who.int/malaria/publications/worldmalaria-report-2015/report/en/ (Accessed on: 15 April,2021)

WHO, 2016. World Malaria Report, 2016. Available at:https://www.who.int/malaria/publications/worldmalaria-report-2016/report/en/ (Accessed on: 18 April,2021)

WHO, 2018. World Malaria Report. Available at: https://www.who.int/malaria/publications/worldmalaria-report-2018/report/en/\#: :text=The $\%$ 20latest $\% 20$ report $\% 2 \mathrm{C} \% 20$ released $\% 20$ on,in\%20the $\% 20$ fight $\% 20$ against $\% 20$ malaria. (Accessed on: 15 April,2021)

Willcox, M., Bodeker, G., Bourdy, G., Dhingra, V., Falquet, J., Ferreira, J.F., Graz, B., Hirt, H.M., Hsu, E., de Magalhães, P.M. and Provendier, D. 2004. Artemisia аппиа as a traditional herbal antimalarial. Tradit. med. plant Malar. 4, 43-59.

Woguem, V., Fogang, H.P., Maggi, F., Tapondjou, L.A., Womeni, H.M., Quassinti, L., Bramucci, M., Vitali, L.A., Petrelli, D., Lupidi, G. and Papa, F. 2014. Volatile oil from striped African pepper (Xylopia parviflora, Annonaceae) possesses notable chemopreventive, anti-inflammatory and antimicrobial potential. Food chem. 149, 183-189. DOI: https://doi.org/10.1016/j.foodchem.2013.10.093

Wongsrichanalai, C., Pickard, A.L., Wernsdorfer, W.H. and Meshnick, S.R. 2002. Epidemiology of drug-resistant malaria. Lancet Infect. Dis. 2, 209-218. DOI: https://doi.org/10.1016/S1473-3099(02)00239-6 